\title{
Book Review: Sarbani Sen Vengadasalam. (2019). New Postcolonial Dialectics: An Intercultural Comparison of Indian and Nigerian English Plays. Newcastle upon Tyne, UK: Cambridge Scholars Publishing
}

\author{
Abha Sood (Corresponding author) \\ Department of English, Monmouth University, USA \\ Email: apatel@monmouth.edu
}

Received: $19 / 05 / 2020$

Accepted: 10/06/2020

Published: 01/07/2020

Volume: 1 Issue: 2

How to cite this paper: Sood, A. (2020). Review: Sarbani Sen Vengadasalam. (2019). New

Postcolonial Dialectics: An Intercultural Comparison of Indian and Nigerian English Plays. Newcastle upon Tyne, UK: Cambridge Scholars Publishing. Journal of Critical Studies in Language and Literature, 1(2), 48-51

DOI: https://doi.org/10.46809/jcsll.v1i2.11

Copyright (C) 2020 by author(s) and Global Talent Academy Ltd. This work is licensed under the Creative Commons Attribution International License (CC BY 4.0).

http://creativecommons.org/licenses/by/4.0/

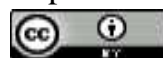

\begin{abstract}
Vengadasalam's book offers a comparison of the literary and artistic practices and philosophies of three authors, two from India (Rabindranath Tagore and Badal Sircar) and one from Nigeria (Wole Soyinka), by examining their dramatic works: four plays in total, which offer an evaluation of the pre and post-independence national environment. Vengadaslam posits that the existing terminology for examining their work in the postcolonial context is insufficient and suggests a new term: "intercultural" to fully explore the magnitude of these writers" art and the extent of their influence.
\end{abstract}

Keywords: Postcolonialism, Interculturalism, Ecocriticism, Weriters of Color, Social Changes

\section{Review}

Since the formation of the field of Postcolonial studies a few decades ago, several notable critics have contributed to forming the theoretical framework for analyzing literature from the former 'third world' in its various contexts. In this new millennium, specifically, several trends have emerged in Postcolonial studies which encompass a variety of other movements as well. 'Postcolonial' interpretations have been applied to fields as varied as science fiction, ecocriticism, pre-colonial writing and philosophy, gender and queer studies, covering literature from every corner of the world, using theory in varying degrees and iterations to analyze every aspect of writing by non-western writers, including writers of 'color' resident and active in western nations. Every year sees the publication of edited collections of essays by multiple scholars, or volumes of criticism by one (or two) authors, which attempt to re-cover old ground or explore hitherto neglected genres and/or writers under the ever-expanding umbrella of Postcolonial theory and interpretation, with varying degrees of success.

Some among these are more successful than others and are examined closely for their contribution to the field by remarkable critics ${ }^{1}$. Vilashini Cooppan's Worlds Within: National Narratives and Global Connections in Postcolonial Writing (2009), for instance, offers a very pertinent and "timely" (Anker, 2011, p. 588) study that interprets nationalisms using a "psychoanalytic hermeneutic" (Anker, 2011, p. 588), which challenges prevailing notions of the global. While the collection edited by Ashcroft et al. (2012) offers an array of insights on Postcolonialism, the 35 essays within covering "conceptual and methodological issues" (Breto, 2013, p. 219) that extend the scope of the discipline and apply it to concerns of race, ethnicity, translation, language, migration, among many others. Another subject that concerns several critics is the 
connection between Postcolonialism and Marxist thought (specifically in Subaltern Studies): Vivek Chibber explores the Lazarus value of "Marxist rethinking" (Hitchcock, 2015, p. 356) in his Postcolonial Theory and the Specter of Capital (2013), while Neil proposes that Marxism and Postcolonialism are antithetical ideas in his The Postcolonial Unconscious (2011). The Bloomsbury Introduction to Postcolonial Writing (2018), edited by Jenni Ramone, on the other hand ambitiously attempts to "register the emergence of new intellectual arenas in Postcolonial Studies via largely anglophone contexts" (Toth, 2019, p. 372). The trending field of Ecocriticism has been addressed effectively in volumes by Graham Huggan and Helen Tiffin in Postcolonial Ecocriticism: Literature, Animals, Envrionment (2010), and Bonnie Roos and Alex Hunt in Postcolonial Green: Environmental Politics and World Narratives (2010), among several others.

Likewise, Vengadasalam's critique of three renowned writers from India and Nigeria provides a highly lucid overview of the relevance and impact of their work. She offers an informative assessment of the aspects of their upbringing, family, education and personality traits that contributed to their artistic choices and development. The book also displays a very vast knowledge of the political and historical backdrop of India and Nigeria, the progress of the colonial/British occupation, the independence struggle, the national cultural and social/political awakening, the aesthetic and social movements in the US and Europe, and the impact of all of these on the literature that emerged during the early 20th century and later.

Vengadasalam uses critique from numerous sources, new and old, to fully realize the de-colonization project, consciously taken up by intellectuals to reassert their equality and personhood. She effectively iterates the value of the Indian nationalist movement as well as the Negritude movement for the specific, pre-independence time to create and rouse a national consciousness. Yet she also acknowledges that those movements could not be sustained or resolve the crises faced by newly independent nations. She agrees with Henry Louis Gates' statement that "To reconstruct effectively, one needs to deconstruct - especially old myths and metaphysics about, as well as in, Africa" (as quoted in Vengadasalam, 2019, p. 11) but points out the limitations of such a reconstruction, which ignores Western ideas while re-adopting past formulations of the nation, since the nation has moved on and cannot neglect the cultural interference and confluence that has occurred. Hence, her critique addresses issues of reworking culture and language while forging ahead "into the broader spectrum of an eclectic internationalism" (12), and perfectly describes what most true, committed intellectuals strive for, while acknowledging that it is important to include the West while avoiding derivativeness.

The book is organized into six chapters, each chapter divided into two sections. Chapter One, in its first section, offers an effortless representation of the history and intellectual development in colonial India and Nigeria. Her stance remains thoughtful and objective as she recognizes the task of the intellectual in a post-independence context. She provides an accessible overview of the history of colonialism, and its methods and purposes in India and Nigeria. Even as some of the analysis covers ground traversed by prior writers, her detailed evaluation of the effect of the colonial process, especially through the introduction of English (and thus, English/Western culture) as the language of influence on the psyche of the colonized, can provide a novice reader with ample insight and information. She reiterates the explorations of other scholars, revealing a systematic dismantling of the traditional patterns of culture in colonized nations, as with India and Nigeria, a new version of the "brown" Englishman, mocked and ridiculed in British literature and circles (6-7). She precisely pinpoints this moment of realization (7) that spurred the creation of and return to indigenous literary forms and narratives, which constructions, later, consciously acknowledge and exploit Western literary forms and genres as well.

The first section of Chapter One also provides a clear listing of the extensive and varied reception the three writers received, while it also states that these three writers are representatively intercultural. The second section first evaluates the relevance of various significant theories, as in postmodernism, post-structuralism, black aesthetics, and ancient Indian poetics, and theorists such as Fanon, Edward Said, JanMohamed, Gauri Viswanathan, Gayatri Chakravorty Spivak, and Homi K. Bhabha, to examine literature produced in response to colonial and postcolonial experience. Then it offers a rationale for a new scaffolding of interculturalism to evaluate the drama of Tagore, Soyinka and Sircar more fully and adequately by attempting to locate a balance between the local and the international, in terms of values and themes, and the present and the future, in terms of sources.

Thereafter, her thorough analysis of the personal philosophy of Rabindranath Tagore, Wole Soyinka, and Badal Sircar, their creative output and specific works from their repertoire is conducted under the rubric of two phases, inspired perhaps by Fanon's hypothesis (37) of the growth of a unique individual national identity, finally comfortable with itself after having gone through the first two phases of cultural co-option or adoption, followed by reactionary nationalism and subsequent 'liberation.' Each chapter provides, first, a section on the writer's "philosophy and dramaturgy," the backdrop for his growth as an individual who evaluates the nation-formation process in light of the colonial, postcolonial and neo-colonial experience, and second, a section on an "intercultural" analysis of one specific play by that writer. Her analysis of each writer's dramatic work, its critical, historical and intercultural imperative is explored fully through its dialectical function and its very topical relationship to its audience.

For instance, in "Chapter Four: Indian Interculturalism-Phase Two," in the first section, Vengadasalam examines the origins of Badal Sircar's very personal and provocative formation of an Indian, grassroots poetics. Sircar's poetics addressed the needs of and the spirit of the Indian folk theatre experience, mainly to provoke social change and spiritual revival, all of which was inspired by his sensitive finger on the pulse of the Indian ecology, his numerous trips abroad, and his immersion in theatres and cultures of various nations-both western and non-western. Then, in the second section, Vengadasalam studies one of Sircar's plays closely: Micchil (Procession), written in 1972 (149), which, she posits, clearly established 
Sircar's creation of the "third theatre concept" (149) and his avocation as a "political, non-conformist, and radical" dramatist (151).

Vengadasalam's assessment of Sircar's evolution as an artist covers a great deal of ground, exploring his connections with and inspiration by various contemporary dramatists like Jerzy Grotowski, while acknowledging the influence of other experimental dramatists of the mid-twentieth century, like Brecht who like Sircar, used "theatre [w]as a tool ... [to] achieve specific social aims" (153). She goes on to evaluate the selected play in detail, exploring symbols, exposing sociopolitical connections and interpretations while establishing the fact that Sircar's "third theatre" was truly democratic in that it was a theatre of the people, for the people, and eventually, through audience participation and unique dramatic enactment, by the people - a theatre mainly directed at exploring the new Indian consciousness and provoking the conscience of common people.

Considering the scope and length of this text, it would be a very useful volume for a student of postcolonial literature in general as she covers a great deal of historical and theoretical terrain in assessing the development of major nationalist movements in India, the black power and negritude movements in Africa, theoretical terminologies and periods, and offers a clear-sighted perspective on their value for the study of contemporary literary and cultural theory. Even as the text is informative, to some extent it is didactic as well, as it suggests a particular use for such critical tools.

Yet, Vengadasalam's painstaking study of each historical, sociocultural, and political period and the evolving philosophy of these major dramatists is quite valuable in itself. In addition, her argument suggests the need to move beyond those movements as the needs of nations continue to evolve. As she points out, these writers chose to be the conscience of their nations, newly under attack by neo-colonial forces, to provide the hope for regeneration and growth.

In order to encapsulate her message, Dr. Vengadasalam has also suggested a novel term for highlighting the work of these brilliant and impactful writers: interculturalism. This term suggests that the amalgamation of various threads of cultural values and styles (regional, native, folk - Indian or Nigerian/African and Western), is evident in these writers' works, which is an absolute necessity since their work acknowledges the need to recognize, revive, absorb, utilize and transform all forms of cultural and literary knowledge and styles to achieve the purpose of national survival with dignity. As stated very cogently by the writer in Chapter Six: "Choosing to chart a new path in their dramaturgy towards authenticity, the writers propounded and followed interculturalism as a philosophy, ... pragmatic and inescapable in the context of colonial realities" (199). Since what is present in the psyche of the 'post-colonial' individual cannot be effectively extricated, it needs to be utilized proactively and profitably.

While the term 'intercultural' carries implications of Bhabha's term hybridity, yet, according to the author, interculturalism has a singular imperative. It mainly focuses on cultural fusion instead of the creation of a final, new product (the hybrid), with elements of both cultures that can exist independently and generate further discourse and replicate themselves in art forms thereafter.

As stated earlier, the book's greatest value lies in the amount of ground it covers in detailing the work of three major writers who used traditional forms and narratives to fit the need of the times through the subject of their writing, and the act of reaching out to a local as well as global audience, which is clearly necessitated by the times they wrote in.

\section{References}

Anker, E. S. (2011). Review. Cooppan, V. (2009). Worlds within: National Narratives and Global Connections in Postcolonial Writing. Stanford, CA: Stanford University Press. Comparative Literature Studies, 48(4), 588-590. doi:10.5325/complitstudies.48.4.0588.

Breto, I. (2013). Review. Ashcroft, B., Mendis, R., McGonegal, J., and Mukherjee, A. (2012). Literature for Our Times: Postcolonial Studies in the Twenty-first Century. Amsterdam and New York: Rodopi. Atlantis, 35(2), 219-225. ISSN: 0210-6124.

Carrigan, Anthony. (2012). Review. Roos, B. and Hunt, A. (2010). Postcolonial Green: Environmental Politics and World Narratives, Charlottesville and London: University of Virginia Press. The Modern Language Review, 107(3), 911-913. Doi: 10.5699/modelangrevi.107.3.0911.

Hitchcock, P. (2015). Review. Chibber, V. (2013). Postcolonial Theory and the Specter of Capital. New York: Verso. The Comparatist, 39, 355-364. doi: 10.2307/26254734.

Kelly, Riona. (2013). Review. Exploring narratives of global justice and sustainability: The rise of Postcolonial ecocriticism. DeLoughrey, E. and Handley, G. B. (2011). Postcolonial Ecologies: Literatures of the Environment, New York: Oxford, UP. \& Roos, B. and Hunt, A. (2010). Postcolonial Green: Environmental Politics and World Narratives, Charlottesville and London: University of Virginia Press. Modern Fiction Studies, 59(1), 175-181.

Taylor, C. (2015). Review. Neil Lazarus. (2011). The postcolonial Unconscious. New York: Cambridge University Press. Modern Philology, 112(4), E339-E345. doi:10.1086/679355.

Toth, H. G. (2019). Review. Ramone, J. (2018). The Bloomsbury Introduction to Postcolonial Writing: New Contexts, New Narratives, New Debates. London: Bloomsbury. The Modern Language Review, 114(2), $372-373$. doi:10.5699/modelangrevi.114.2.0372.

Vadde, A. (2011). Review. Huggan, G. and Tiffin H. (2010). Postcolonial Ecocriticism: Literature, Animals, Environment, London and New York: Routledge. Contemporary Literature, 52(3), 565-573. E-ISSN 1548-9949/11/0002-0565. 
Vengadasalam, S. S. (2019). New postcolonial Dialectics: An Intercultural Comparison of Indian and Nigerian English Plays. Newcastle upon Tyne, UK: Cambridge Scholars Publishing.

\section{Endnotes}

1 This evaluation is arrived at by my perusal of various publications on postcolonial theory and writing published in the last decade alone, as listed in the References above. 